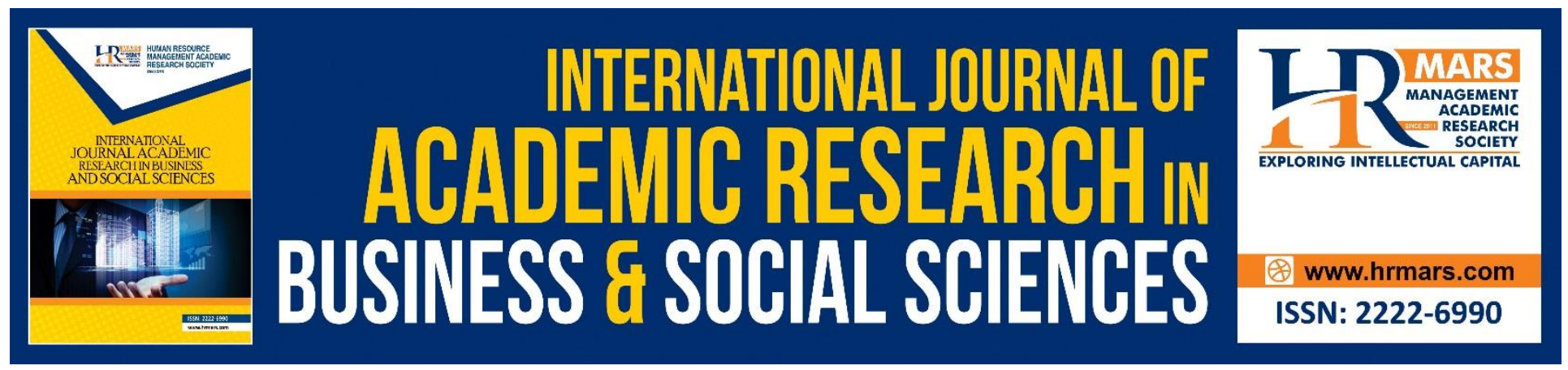

\title{
Modeling of Emotional Resilience Factors through Challenging Situations for Head Teachers: A Review
}

\author{
Hamidah Che Abdul Hamid and Puspa Liza Ghazali
}

To Link this Article: http://dx.doi.org/10.6007/IJARBSS/v8-i11/5197

DOI: $10.6007 /$ IJARBSS/v8-i11/5197

Received: 02 Nov 2018, Revised: 26 Nov 2018, Accepted: 03 Dec 2018

Published Online: 13 Dec 2018

In-Text Citation: (Hamid \& Ghazali, 2018)

To Cite this Article: Hamid, H. C. A., \& Ghazali, P. L. (2018). Modeling of Emotional Resilience Factors through Challenging Situations for Head Teachers: A Review. International Journal of Academic Research in Business and Social Sciences, 8(11), 1379-1388.

\section{Copyright: (c) 2018 The Author(s)}

Published by Human Resource Management Academic Research Society (www.hrmars.com)

This article is published under the Creative Commons Attribution (CC BY 4.0) license. Anyone may reproduce, distribute, translate and create derivative works of this article (for both commercial and non-commercial purposes), subject to full attribution to the original publication and authors. The full terms of this license may be seen at: $\underline{\text { http://creativecommons.org/licences/by/4.0/legalcode }}$

Vol. 8, No. 11, 2018, Pg. 1379 - 1388

Full Terms \& Conditions of access and use can be found at http://hrmars.com/index.php/pages/detail/publication-ethics 


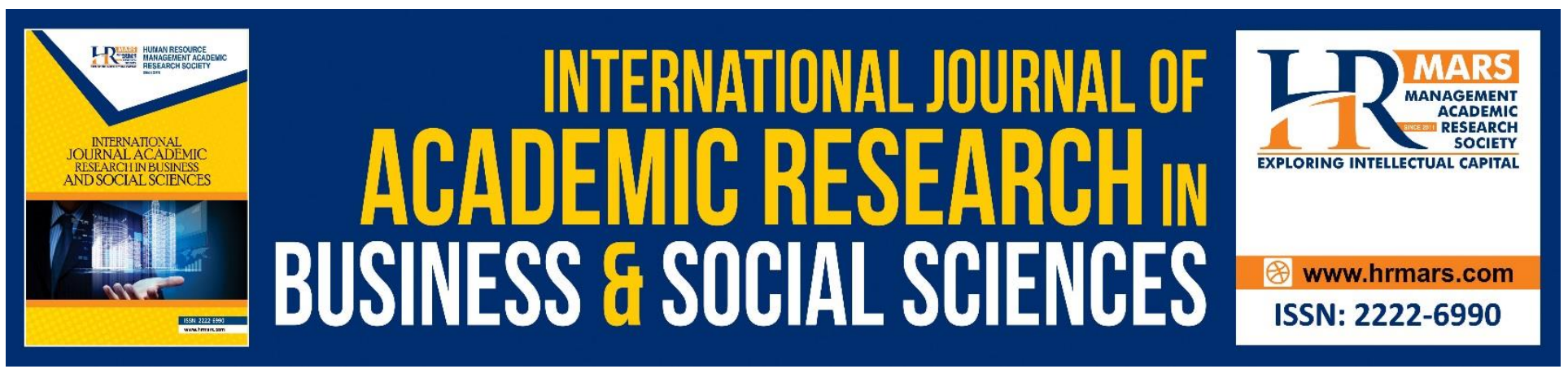

\title{
Modeling of Emotional Resilience Factors through Challenging Situations for Head Teachers: A Review
}

\author{
'Hamidah Che Abdul Hamid and 2Puspa Liza Ghazali \\ 1,2 Faculty of Economic and Management Sciences, Universiti Sultan Zainal \\ Abidin, 21300 Kuala Nerus, Malaysia \\ 1 Jabatan Pendidikan Negeri Kelantan, Kompleks JPN Tunjong, 16010 Kota Bharu, Malaysia
}

\begin{abstract}
Many previous studies have been done to determine qualities create resilient leaders to cope everyday workload in schools and the impacts to the school's performance. This study intends to identify the factors that contribute to Emotional Resilience Learning through Challenging Situations and hence to find out the effects towards school performance. It aimed to model emotional resilience among head teachers in a few Asian countries and then a comparison across the model.
\end{abstract}

Keywords: Head teachers, Emotional Resilience, Emotional Intelligence, Challenging Situations and School Performance.

\section{INTRODUCTION}

\section{Introduction to Emotional Resilience}

Rapid, disruptive change is today's normal. It comes in bubbles, waves and sometimes tsunamis. In order to manage all the changes and challenges situations, leaders need to be agile and resilient. Resilient leaders are connected to the emotional intelligence competencies by author Daniel Goleman. They involve self awareness, managing oneself, awareness of others and managing relationships. In his new book, Social Intelligence, Goleman takes us more deeply into underlying cognitive functioning and broadens the context to include society which is very crucial for head teachers to apply in managing the school. It is these EQ competencies that help us make behavioral changes that strengthen our resilience and agility, bridge "know-do" gaps and sustain change, challenging situations and value over time. However, a range of recent empirical research confirms that there is no short cut to achieve success being a head teacher in managing the school. A vast array of leadership style must be learn which current policy focus upon instructional leadership, or leadership for learning (Hallinger, 2010), accompanied by an equally strong focus provided by 'transformational leadership' theory (eg Leithwood et al,2006) upon the quality of the teaching and learning environment, whole-school vision, setting direction, redesigning organizational structures, and developing and sustaining the capacities of teachers to teach to their best through comprehensive and differentiated professional learning and development opportunities.

\section{Problem Statement}

In October 2011, Malaysian Ministry of Education launched a comprehensive review of education system in order to develop a new National Education Blueprint preparing Malaysia's children to cater 
the global needs of the $21^{\text {st }}$ century, and increased public and parental expectations of education policy. There are eleven shifts to transform the system.

It is therefore the fifth shift which is to ensure high-performing school leaders in every school, which is the quality of school leaders is needed, second biggest school-based factor in determining student outcomes, after teacher quality. International research on school leadership shows that an outstanding principal is one who focused on instructional and not administrative leadership can raise student outcomes by as much as 20\% (Malaysian Education Blueprint 2013-2015, Executive Summary).

Hence, the comprehensive plan is not achieved if the head teachers could not overcome challenging situations and unable to have the resilient competencies. The outcome of the school shows the quality of the head teachers. In the study there will be appropriate analysis on emotional resilient learning through challenges that can develop the quality of head teachers in managing the school and towards the education expectations among elite and high performing schools through school ranking in district, state or national level.

School head teachers are responsible, above all, for establishing the expectations, aspirations and practices of all those in the school. They need to model academic optimism, hope, trust and moral purpose at all times and in all circumstances and this requires resilience as it is a long journey. Previous research shows that most school leadership effects on student wellbeing and achievement are indirect. Successful leaders work with and through others. To do so successfully requires that they know their staff well so that they can build their capacities for resilience in ways that are appropriate to each individual and the needs of students. Therefore, further research on emotional resilience among the school leadership is crucial to develop the quality leadership in facing the challenges and opportunities in future. Helping teachers and students at school helps not only organizations but families, communities and our society

\section{LITERATURE REVIEW Theoretical}

\section{Review}

There is a wealth of research related to school leadership over the past thirty years reveals an evolving series of theories from the 'Great Man' and 'Trait' theories prevalent in the late 1980s, followed by style theory and situational theories, to the more recent emphasis on 'Transformational' and 'Transactional' Leadership (Leithwood, 1992; Pearce and Conger, 2003; Bottery, 2004; Harris, 2008). Whilst many different leadership theories have emerged over time, most can be classified as one of the eight major types shown in Table 2.1. 
INTERNATIONAL JOURNAL OF ACADEMIC RESEARCH IN BUSINESS AND SOCIAL SCIENCES

Vol. 8, No. 11, Nov, 2018, E-ISSN: 2222-6990 @ 2018 HRMARS

Table 2.1: Overview of leadership theories

\begin{tabular}{|c|c|}
\hline $\begin{array}{l}\text { Great Man } \\
\text { Theories }\end{array}$ & $\begin{array}{l}\text { Great Man theories assume that the capacity for leadership is } \\
\text { inherent - that great leaders are bom not made. The term 'Great } \\
\text { Man' was used because, at the time, leadership was thought of } \\
\text { primarily as a male quality, especially in terms of military } \\
\text { leadership. }\end{array}$ \\
\hline Trait Theories & $\begin{array}{l}\text { Similar in some ways to 'Great Man' theories, trait theories } \\
\text { assume that people inherit certain qualities and traits that make } \\
\text { them better suited to leadership. Trait theories often identify } \\
\text { particular personality or behavioural characteristics shared by } \\
\text { leaders. }\end{array}$ \\
\hline Contingency Theories & $\begin{array}{l}\text { Contingency theories of leadership focus on particular variables } \\
\text { related to the environment that might determine which } \\
\text { particular style of leadership is best suited for the situation. } \\
\text { According to this theory, no leadership style is best in all } \\
\text { situations. }\end{array}$ \\
\hline Situational Leadership & $\begin{array}{l}\text { Situational theories propose that leaders choose the best course } \\
\text { of action based upon situational variables. Different styles of } \\
\text { leadership may be more appropriate for certain types of } \\
\text { decision-making. }\end{array}$ \\
\hline Behavioural Theories & $\begin{array}{l}\text { Behavioural theories of leadership are based upon the belief } \\
\text { that great leaders are made, not born. Rooted in behaviourism, } \\
\text { this leadership theory focuses on the actions of leaders not on } \\
\text { mental qualities or internal states. }\end{array}$ \\
\hline Management Theories & $\begin{array}{l}\text { Management theories (also known as 'Transactional theories') } \\
\text { focus on the role of supervision, organisation and group } \\
\text { performance. These theories base leadership on a system of } \\
\text { rewards and punishments. }\end{array}$ \\
\hline Transformational Theories & $\begin{array}{l}\text { Transformational theories (also known as Relationship theories') } \\
\text { focus upon the connections formed between leaders and } \\
\text { followers. Transformational leaders motivate and inspire people } \\
\text { by helping group members see the importance and higher good } \\
\text { of the task. This style often has high ethical and moral standards. }\end{array}$ \\
\hline
\end{tabular}

Adapted from Van Wart (2003)

In the late 1990s the leadership world, particularly the business world, was dominated by literature that focused on transactional leadership:

If there was any message from leaders of such literature (which was largely written for the business world), it was in an age of relative economic stability, the leaders job was a rational job, one of Transactional leadership. This suggested Day at al. (2000), is essentially a form of scientific managerialism, in which leaders exercise power and 
INTERNATIONAL JOURNAL OF ACADEMIC RESEARCH IN BUSINESS AND SOCIAL SCIENCES Vol. 8, No. 11, Nov, 2018, E-ISSN: 2222-6990 @ 2018 HRMARS

influence through controlling the rewards in and organization, reward the can offer or withhold from work force (Bottery, 2004:16).

This transactional model of leadership was designed specifically to deal with a stable and predictable economy where the use of power and the exchange of favours to motivate the workforce were prevalent.

When $21^{\text {st }}$ century arrived and economy started to experience change, instability and challenges situation give great impact, the traditional and rational transactional replaced. As a result of this, transformational leadership quickly became aligned with charismatic theories of leadership of the day:

transformational theories may have too narrow a focus, in the process neglecting such issues as task oriented behavior, the interaction of a leader with superiors, peers or outsiders, and of the influence and dynamics of leadership upon a group or an organization (Yukl, 1999:47)

Yukl argues that the transformational and charismatic theories of leadership were brought about as business and management tools to ensure the workers embrace the managerial and sometimes capitalist 'values' of an organization, and he cautioned against borrowing models and theories and applying them randomly to educational practices. Educational leadership and management have attracted a great deal of theoretical interest and debate and there appears to be no single definition that satisfies everyone. Dimmock (1999:442) provides one of the few distinctions amongst these concepts whilst also acknowledging that there are competing definitions:

School leaders [experience] tensions between competing elements of leadership, management and administration. Irrespective of how these terms are define, school leaders experience difficulty in deciding the balance between higher order tasks designed to improve staff, student and school performance (leadership), routine maintenance of present operations (management) and lower order duties (administration).

There was, however, a paradigm shift in the perception of educational leadership with Malaysian Education Blue Print of the fifth shift that the school leaders were being asked to be high performing and could develop and inspire their teachers' commitment to and capacity for ensuring the best possible learning opportunities for their pupils. This new agenda required a transformation in how school leaders delivered their school improvement plans, relying heavily on collaboration and multiagency working. Educational leadership was, and continues to be, seen as an interactive, social process:

The attributes that this conception implies - ability to live with uncertainty and learn from mistakes, agility, adaptability, preparedness to distribute leadership, work across boundaries and build trusting relationships - are likely to become even more important in the future based on current contextual trends (Glatter, 2009:226).

\section{Challenging Situations}

In the exploration of leadership challenges Leithwood and Steinbach (1995) found that leaders generally categories situations into either structured or unstructured and that a leader's actions would vary according to how the leader categorized the situation. For those situations that are structured or familiar, leaders respond in habitual ways that have worked in the past and that have yielded acceptable results. However, when a situation is unstructured, this will often present a challenge and leaders sometimes respond in unprogrammed ways. Leithwood and Steinbach explain 
that when leaders run into an unstructured situation, they run into dilemma. The dilemma presented by a new situation and the need to perform can lead to disorienting challenging situation. There has been a relatively limited amount of research completed within the educational sector that focuses on how individuals and organizations cope with challenging situations and what it is that enables them to do so effectively. Tripp's (1993) research into critical incidents. Carrying out a search on critical incidents reveal that much of the literature is concerned with the emergency services with business, military or political crises - and very little is concerned with education. Consequently there is no universal definition of a critical incident, but terms like 'emergency', 'major incident', 'accident', 'critical incident' and 'disaster' (Flin, 1996) are used interchangeably to describe similar events, although major incidents and disasters are seen to be on a larger scale.

Educational research shows that incidents within school very rarely turn into emergencies or develop into a crisis. They are often smaller incidents that can take a greater significance depending on the context and those involved (Bennis, 2003; Bottery, 2004; Mander, 2008). However, coping with the anxiety and stress an incident raises, making well-informed and effective decisions and managing others when coping with these incidents places considerable pressure on those involved. Mander's (2008) study shows that whilst an incident on its own might not be challenging, when combine with other incidents and leadership emotions it can become so.

This is of real significance in terms of emotional reactions and resilience of head teachers when dealing with challenging situations and the link between emotional and educational leadership. Mander (2008:8) suggests that sometimes these challenges are so critical that they place considerable pressure on those involved with them, whilst at other times they are small, often insignificant, but 'their cumulative effect can be felt to be equally challenging'. In line with the work of Gronn (1999) a central tenet of Mander's research is that there are certain events, experience or occurrences in the lives and history of leaders that may be instrumental in shaping their attitudes and ability to cope with problems and dilemmas.

\section{Emotional Resilience}

The concept of emotional resilience and how this intersects with the other factors that influence one's capacity to cope with challenging situations is evident in the literature. Flin (1996:8) describes emotional resilience as 'the capacity to withstand and renew oneself in light of life stressors, thrive and make meaning from challenge' and purposes one of the significant factors in coping with crisis is one's ability to cope with stress:

The central process involved in building resilience is the training and development of adaptive coping skills. Coping strategies are generally either outwardly focused on the problem (problem solving), inwardly focused on emotions (emotion-focused) or socially focused, such as emotional support from others.

According to Beatty (2008), our emotions arise in our daily lives largely in terms of problems to be solved. In challenging situations, therefore, the relationship dimension is likely to surface because the social and emotional leadership dimensions often intensify. Beatty (2008:7) is very clear about the significance of emotions in developing and sustaining relationships, especially when there is conflict or challenge:

To maintain relationships, one must understand the emotions that endanger them, especially in times of betrayal and wounding. We all need to learn to engage in reflective emotional meaning making to be able to enact our commitment to connectedness. This is how we sustain the relationships upon which our very survival depends. 
Leadership is stressful. School leadership calls for physical, emotional and intellectual energy. (Harris 2007; West-Burnham 2009; Allen 2009). Flintham (2003a, 22) identifies the need for school leaders to have 'high levels of emotional resilience'. Definitions of resilience include references to persisting in the face difficulty; maintaining hope against the odds; being optimistic; being courageous; having inner resourcefulness; showing the capacity to recover quickly from setbacks; having moral purpose. Patterson and Kelleher (2005) refer to the term resilience as being 'a convenient label to describe things that bounce back ' $(2005,1)$ and defines it as 'using your energy productively to emerge from adversity stronger than ever' $(2005,3)$. Barret $(2010,399)$ describes resilience as 'the ability of an entity to withstand and bounce back from shocks that test its ability for continuous profitable functioning' adding that 'it is essential to invest in resilience'. There is considerable agreement among head teachers concerning what impacts positively on their sense of well-being. A healthy work-life balance is frequently cited, along with pursuing other professional opportunities; time for reflection; and networking with other head teachers (Flintham 2003a, 2003b,Pass, 2009, Patterson, 2006, Steward, 2011). These are all factors which can be regarded as 'activities' which require setting aside time for a particular purpose. Well-being is also influenced by attitude of mind, however.

Boyatzis, Smith and Blaize (2006) argue that the power stress associated with leadership adversely affects the leader's ability to sustain him or herself overtime, and shows the benefits of coaching others as a means of maintaining compassion for self, which makes the role more sustainable. If stress is inevitable, what is it that tips individuals into a state where they and/or others recognize that they cannot function effectively? Those who burned out were unable to stand back and reflect on what was happening to them. Those who did not suffer from burnout were less concerned with recognition and more with inherent challenge of their role.

They had a sense of purpose which was not tied to their job. They were more able to adapt to changes in their surroundings; they were able to stand back and reflect on what was happening to them, they had a strong sense of internally referenced identity, and did not need to rely on external verification. They are proactive, investing energy in what was within their control even if that was only their own behavior. Those who cope best with stress and avoided burnout had a greater degree of selfawareness and self-management than those who experienced burnout, suggesting a connection between these attributes (identified by Goleman (1998) as being essential for leadership) and resilience.

Harris (2007) argues that the emotional competency model promoted by Goleman (1998) is not sufficient. We may learn emotionally intelligent ways to behave, but without what she calls 'deep inner awareness' ( $p 5$ ) our behavior is an act, contrived to mask our shadow side. The 'act may have a positive impact on the culture of organization, but there is a cost to the leader which increases with the increased discrepancy between what is actually felt and how the leader has learned to behave (Humphrey, 2012). Harris outlines the importance of gaining deep self-knowledge which involves embracing not just those aspects of our personality that are culturally acceptable, but also

'the more neglected aspects of self, such as the vulnerable self that is hidden behind learned defenses and the shadow self (Jung and Von Franz 1964) that is often denied until it erupts in protest at times of stress to damage self and others' (Harris 2007,51)

Self-awareness has an impact on self-confidence, the absence of which, maintains Goleman $(1998,69)$ 
'can manifest itself in feelings of helplessness, powerlessness and crippling self-doubt'. Real selfconfidence (as distinct from brashness or arrogance) must be aligned with reality, which heightens the need for self-awareness. Self-confidence is seen as being closely aligned with self-efficacy: '...we have to have belief in our skills in order to use them at their best' (Goleman 1998, 70). Self-awareness is related to individual mood which is the volume of positive energy that bring interactions reflecting the attitudes towards the past, present and future (Bharwaney 2015, 2). The essential part of to understand Emotional Resilience is divided into two personal resilience and team resilience as (Bharwaney, 2015) give the depth idea on how emotional resilience can be understood. Selfawareness must be come along with team awareness as the head teacher inspiring others and manage others to accomplish the mission. Leadership must come along with emotional resilience in overcoming challenges and managing others for school improvement.

The National Research Council and the Institute of Medicine (Eccles \& Gootman, 2002) concluded that supportive relationships appear to serve as 'critical medium' of development providing the opportunity for the healthy physical, intellectual, psychological and social growth of youth. Additional research on parenting and teacher 'styles' provide clear evidence that the authoritative/democratic style with its focus on warmth/connection, guidance/regulation and psychological autonomy/responsibility is highly correlated with positive outcomes including higher academic achievement, greater psychological adjustment, social competence, self reliance, creativity and responsibility (Barber \& Olsen, 1997; Cohen \& Rice, 1997; Dornbusch, et. al, 1987; Herman, et.al, 1997; Lahey, et.al, 1999; Paulson, et.al, 1997).

\section{CONCLUSION}

In conclusion, by doing this review researcher will proceed with the empirical study by collecting the data from head teachers of primary school within east coast of peninsular Malaysia. This data will be analyzed using appropriate leadership and emotional resilience model to find out what are the major determinants of high performing head teachers, find out its impacts toward schools' performance. By collecting data from various types of schools, researcher to understand more completely the challenging situations experienced by primary school head teachers and to interpret how they influence their coping mechanisms. The findings of this study provide evidence that trust and emotional resilience should be considered as a vital part of leadership development and their constructs used in school improvement efforts. This study is hope to provide evidence that self awareness, social awareness and emotional resilience should be considered as a vital part of leadership development and their construct used in school improvement efforts. More studies should be conducted self awareness, social awareness and building emotional resilience to sustain leaders in difficult times. It is also vital for educational studies to continue to explore the intensely how emotional resilience work for the head teachers in managing challenging situations. This needs to reflect the demands of primary school education in the twenty-first century and is a crucial requirement if head teachers are effectively carry out what is an extremely complex and challenging role. 
INTERNATIONAL JOURNAL OF ACADEMIC RESEARCH IN BUSINESS AND SOCIAL SCIENCES

Vol. 8, No. 11, Nov, 2018, E-ISSN: 2222-6990 (C) 2018 HRMARS

\section{REFERRENCES}

Boyatzis, R., R. Smith, and M. Blaize. 2006. "Developing Sustainable Leaders through Coaching and Compassion." Academy of Management Learning and Education 5 (1): 8-24.

Boyatzis, R., McKee, A., \& Goleman, D. (2002). Reawakening your passion for work. Harvard Business Review, 80(4), 86-94,126. https://doi.org/10.1177/0149206311433855

Brown, Z. A., and, Uehara, D.L. Coping with stress: A Resarch Synthesis for Specific Educators. Pacific Resources for Education and Learning, http://www.ericdigest.org/1998-2/coping.htm. Accessed on 1st January 2017

Brownnell, M. (1997) Coping with Stress in the Special Education Classroom: Can Individual Teachers More Effectively Manage Stress. ERIC Digest. Accessed on 4 April 2017, from http://www.prel.org/products/Products/Coping- teacherStress.htm

Chrusciel, D. (2006). Considerations of emotional intelligence (EI) in dealing with change decision management. Management Decision, 44 (5), 644 - 657.

Coakes, S.J., \& Steed, L. (2007). SPSS Version 14.0 for Windows: Analysis Without Anguish. Australia. Joh Wiley \& Sons .Australia Ltd.

Charles C. Manz (2003). Emotional Discipline: The Power to Choose How You Feel. San Francisco: Berett-Koehler Publishers,Inc.

Chan, D. W. (2004). Perceived emotional intelligence and self-efficacy among Chinese teachers in Hong Kong. Personality and Individual Differences, 36, 1781-1795.

Coakes, S. J., Steed, L. \& Price, J. (2008). SPSS: analysis without anguish: version 15.0 for Windows. (First e.d.). Sydney: John Wiley \& Sons Australia.

Crawford, M. (2007) 'Rationality and Emotion in Primary School Leadership: An Exploration of Key Themes', Educational Review, 59(1), 87-98.

Day, C. (2003) 'Successful Leadership in the Twenty-first Century', in Effective Leadership for School Improvement, London: Routledge.

Farber, B. A. (1984) Stress and burnout in suburban teachers, Journal of Educational Research. 77, $325-337$.

Gardner, H. (1983). Frames of mind: The theory of multiple intelligence. New York: Basic Books.

GOLEMAN, D., \& BOYATZIZ, R. (2008). Social intelligence and the biology of leadership social intelligence and the biology of leadership. Harvard Business Review, 86(9), 74-81. https://doi.org/Article

Goleman, D. (1997) Emotional intelligence. New York: Bantam Books. 
INTERNATIONAL JOURNAL OF ACADEMIC RESEARCH IN BUSINESS AND SOCIAL SCIENCES

Vol. 8, No. 11, Nov, 2018, E-ISSN: 2222-6990 (C) 2018 HRMARS

Harris, B. 2007. Supporting the Emotional Work of School Leaders. London: Sage.

Hart, K. (1990) Introducing Stress \& Stress Management to Manager, Journal of Managerial Psychology, Vol. 5, pages 9-16

Hein, S. (1996). Emotional intelligence for everybody: A practical guide to emotional intelligence. Clearwater, Florida: Aristotle Press. Retrieved 17 December 2016, from http://eqi.org/eqe96_1.htm

Hein, S. (2001a). The importance of developing emotional intelligence. Retrieved on 12 April 2017.

Leithwood, K. (1992) 'The Move Towards Transformational Leadership', Educational Leadership, 49(5), 8-12.

Long, B.C. (1995). Stress in the Workplace. ERIC Digest, Accessed on 4April 2017, from http://www.ericdigest.org/1998-2/stress.htm.

Matthews, G.; Zeidner, M.; Roberts, Richard D (2002) Emotional Intelligence: science and Myth (eBook); Cambridge, Mass. MIT Press.

Macintosh, G., \& Stevens, C. (2008). Personality, motives and conflict strategies in everyday service encounters. International Journal of Conflict Management, 19(2), 112-131

Mayer, J.D. and Salovey, P. (1993).“The intelligence of emotional intelligence”, Intelligence, Vol, 17, pp. 443-42. Accessed on 5 January 2017 from http://cat.inist.fr/?a Modele $=$ afficheN\&cpsidt $=3977197$

Martin J., (2007). Now the proof: Work stress does make people mentally ill. New Zealand Herald$\begin{array}{lllll}\text { News Website. } & \text { Accessed } & & \end{array}$ fromhttp://www.nzherald.co.nz/health/news/artical.)

Naidoo, S., and Pau, A. (2008). Emotional Intelligence and perceived stress. Vol.63(3), 148-51. 